\title{
Gamification in education: threats or new opportunities
}

\author{
Alexander P. Biryukov ${ }^{1 *}$, Irina S. Brikoshina ${ }^{1}$, Natalia V. Mikhalevich ${ }^{1}$, Svetlana M. \\ Sycheva $^{1}$, and Ekaterina A. Khalimon ${ }^{1}$ \\ ${ }^{1}$ State University of Management, Institute of Industry Management, Project Management \\ Department, Moscow, Russia
}

\begin{abstract}
This article discusses the expediency and efficiency of implementing gamification in education. This study is a meta-analysis of the modern experience of gamification application obtained from numerous international studies, practical cases, and reports of educational entities. The influence of gamification technologies on cognition and learning processes was proved by hardware neurobiological research of students' brain activity during a game using electroencephalography, functional magnetic resonance tomography, and functional near-infrared spectroscopy. On the basis of an analysis of gamification effects regarding efficiency improvement due to perceptive learning, the conclusions were obtained used in a generalized list of opportunities, problems, and threats of application of gamification elements in education. This study systematizes practical results presented by corporate cases and reference literature, which mention the necessity to use specialized online platforms or automated control systems for systematic implementation of gamification into education. The practical cases in the context of education considered the results of gamification application mainly as positive; however, at the same time, negative results were mentioned, which should be analyzed and which also should be included in the list of threats in this study.
\end{abstract}

Keywords: gamification technologies, education system, neurobiology.

\section{Introduction}

In the recent decade, the course of transformation of national economies has been aimed at the transition to business digitization. The widespread introduction of digital technologies is formulating new realities for their functioning.

Peculiar role in Russia is played by development of an education system for teaching specialists in new professions, which assumes application of network functioning principle of educational entities involving all their resources [1], as well as supplementing conventional education scheme with new educational practices and technologies.

Thus, scientific investigation into gamification concept becomes an obvious trend [2], allowing to combine gaming functions with cognitive. However, quantitative indices available at present for analysis are insufficient to prove efficiency and benefits of

\footnotetext{
${ }^{*}$ Corresponding author: guu.konf@yandex.ru
} 
gamification in education. Herewith, the studies in the field of game sector indicate at increasing number of gamers in the world: there were about 2.5 billion persons in 2019. In Russia more than 65 million people are participants in various computer games [3].

Respectively, application of gamification technologies for involvement of students into education seems to be attractive, though, it requires systematization of theoretical knowledge of main aspects of this concept as well as determination of already revealed advantages and disadvantages of gamification $[4,5]$.

\section{Methods}

This study was based on the following general research methods: searching, collection, systematization, analysis, data comparison, verification of scientific hypothesis about the influence of gamification on a student (research object 1) and on education efficiency (research object 2). In addition, foreign publications were analyzed, as well as practical cases of the Russian and foreign educational entities.

The following criteria were applied for selection of publications: the scientific character of the research presented; description of experiment and practically verified results.

The analysis involved the results of studies performed using functional near-infrared spectroscopy, diffuse optical tomography, functional magnetic resonance tomography; electroencephalography. In addition, technical capabilities of equipment and results of their operation were analyzed.

\section{Results}

The presented experimental results of gamification implementation in education allowed to highlight the most significant opportunities and threats of gamification in education as summarized in Table 1.

Table 1. Generalized list of opportunities, problems and threats of application of gamification elements in education.

\begin{tabular}{|c|c|c|}
\hline Opportunities & Problems & Threats \\
\hline $\begin{array}{l}\text { Improvement of technological } \\
\text { skills }\end{array}$ & $\begin{array}{l}\text { No full-scale studies and } \\
\text { coordinated set of the best practices } \\
\text { of gamification in education }\end{array}$ & $\begin{array}{l}\text { Failure to achieve } \\
\text { learning purposes }\end{array}$ \\
\hline $\begin{array}{l}\text { Orientation at team work and } \\
\text { cooperation }\end{array}$ & $\begin{array}{l}\text { Expensive gamified digital products } \\
\text { preventing their application in } \\
\text { education by educational } \\
\text { establishments with limited funding }\end{array}$ & \multirow[t]{2}{*}{$\begin{array}{l}\text { Game is perceived as a } \\
\text { break from studying, } \\
\text { frivolity }\end{array}$} \\
\hline Upbringing of self-organization & $\begin{array}{l}\text { Educational curriculum-schedule } \\
\text { hinders regular application of } \\
\text { gamification }\end{array}$ & \\
\hline $\begin{array}{l}\text { Measurement of } \\
\text { achievements }\end{array}$ & $\begin{array}{l}\text { Lack of experts with design thinking } \\
\text { and experience of development of } \\
\text { gamification products }\end{array}$ & $\begin{array}{l}\text { Setting the goal to win } \\
\text { the game, not the study }\end{array}$ \\
\hline $\begin{array}{l}\text { Improvement of attention and } \\
\text { labor efficiency }\end{array}$ & Poor organization of gaming process & $\begin{array}{l}\text { Loss of individual } \\
\text { responsibility for } \\
\text { fulfillment of task due to } \\
\text { team responsibility }\end{array}$ \\
\hline $\begin{array}{l}\text { Motivation to studying new and } \\
\text { complicated tasks }\end{array}$ & $\begin{array}{l}\text { No successfully solved complicated } \\
\text { tasks as an incentive for emulation }\end{array}$ & $\begin{array}{l}\text { Loss of interest and } \\
\text { involvement }\end{array}$ \\
\hline $\begin{array}{l}\text { Teaching decision making under } \\
\text { conditions of uncertainty, }\end{array}$ & $\begin{array}{l}\text { Modern cases of gamification are } \\
\text { not beyond the education limits } \\
\text { (exclusion: } \quad \text { application of }\end{array}$ & $\begin{array}{l}\text { Loss of boundaries } \\
\text { between game and }\end{array}$ \\
\hline
\end{tabular}




\begin{tabular}{|c|c|c|}
\hline $\begin{array}{l}\text { insufficiency, and } \\
\text { of data }\end{array}$ & $\begin{array}{l}\text { gamification in } \quad \text { business } \\
\text { environment) }\end{array}$ & $\begin{array}{l}\text { education, game and } \\
\text { reality }\end{array}$ \\
\hline
\end{tabular}

\section{Discussion}

Modern principles, methods, and elements of gamification concept are described in details in reports of major world universities, global conferences, and international forums.

Thus, according to the report of Massachusetts Institute of Technology of 2009 [6], the gamification principles are comprised of three main properties of its ancestor, game: unified and clear set of rules, rapid feedback system, as well as distinctly formulated target.

These principles are used also in traditional education; however, after addition of game mechanics, learning becomes more attractive for audience not only involving participants in the game but also promoting them to self-development and achievement of results.

In the report by World Governmental Summit 2016, the elements of gamification are subdivided into three categories:

Mechanical elements most often are arranged in the storytelling format and based on adaption of learning material using increment progressing.

Personal elements are based on formation of student's profile, where his personal and group achievements are reflected.

Emotional elements use the psychological technique of flow state, according to which students involved in the game transit into mental state and are totally concentrated on activity and achievement of results.

Peculiar influence on successful implementation of gamification is exerted by freedom of participants' actions comprised of 5 freedoms of game: the freedom to fail; the freedom to experiment; the freedom of self-expression, the freedom of efforts, the freedom of interpretation [6].

The influence of visualization on brain neural activity during game is confirmed by various neurobiological investigations [7] using electroencephalography, functional magnetic resonance tomography, and functional near-infrared spectroscopy. As a consequence, the conclusions about improvement of efficiency and attention have been made.

The works [8-11] describe advantages of gamification in higher education and provide proofs of improvement of team relations, involvement, motivation, susceptibility to learning, practical skills deepening, satisfaction and achievements of students. Many authors specializing in gamification of education mention its positive effects: improvement of motivation and involvement into education, development of healthy competition $[9,12]$.

Let us consider some examples of successful adaptation of gamification technologies for education.

Minecraft is a computer game, worldwide sales are over 120 million units; and Minecraft EDU is a special version of the game adapted for use in schools: used in more than 100 countries of the world [5].

ClassDojo is a service allowing teacher to provide instant feedback to pupils in game form.

Kahoot is a learning platform allowing to develop gamified tests; for instance, a teacher demonstrates on screen test questions with variants of answers, the students should response as quick as possible to obtain higher score. The platform is used by more than 3.5 million teachers, the investments to the project are about USD 16.5 million [13].

Duolingo is a service for independent learning of foreign languages in game form. It is used by more than 15 million customers. The results of implementation of gamification into LinguaLeo are as follows: activation increased by $30 \%$, user retention increased by $15 \%$, virtual traffic is $10-30 \%$ of main one [14]. 


\section{Conclusion}

While developing own digital educational program, the teacher should play various roles, to be an innovator like entrepreneurs, an empath like psychologists, a manager [15].

Herewith, the importance of practical research based on comparison of reference and experimental groups of students to reveal weak and strong sides of programs with gamification elements and search for ways of their improvement, cannot be overestimated.

The systematized in this work opportunities and threats will assist future design thinkers to consider them upon development of own gamified educational programs.

\section{References}

1. G.P. Kuzina, E-management, 2, 89-96 (2020)

2. J. Majuri, J. Koivisto, J. Hamari, Gamification of Education and Learning: A Review of Empirical Literature, in Proceedings of the GamiFIN Conference 2018, May 21-23, Pori, Finland, vol. 2186, 11-19 (2018)

3. I.A. Sedykh, Industriya komp'yuternykh igr-2020 [Computer games industry-2020] (Centre of Development Institute, Moscow, 2020)

4. H.Y. Kwon, K. Özpolat, INFORM Transaction on Education, 21(2), 67-81 (2020). https://doi.org/10.1287/ited.2019.0227

5. A. Itenberg, Shkol'nyye igry: kak motivirovat' novoye pokoleniye k uchebe [School games: how to motivate a new generation to learn]. Forbes (2017). Accessed on: November 07, 2020. [Online]. Available: https://www.forbes.ru/tehnologii/347717shkolnye-igry-kak-motivirovat-novoe-pokolenie-k-uchebe

6. World Government Summit, Oxford Analytica, Gamification and the future of education 2016 (2016). Accessed on: November 02, 2020. [Online]. Available: https://www.worldgovernmentsummit.org/api/publications/document?id=2b0d6ac4e97c-6578-b2f8-ff0000a7ddb6

7. M.A. Sitnikova, Belgorod State University Scientific Bulletin Humanities Philology Journalism Pedagogy Psychology, 14(235), 136-142 (2016)

8. J. R. Chapman, P. J. Rich, Journal of Education for Busines, 93(7), 314-321 (2018)

9. J. Dias, The International Journal of Management Education, 15(1), 98-111 (2017). https://doi.org/10.1016/j.ijme.2017.01.002

10. L. de-Marcos, A. Garcia-Cabot, E. Garcia-Lopez, The International Journal of Engineering Education, 33(1A), 66-73 (2017)

11. S. Villagrasa, D. Fonseca, E. Redondo, J. Duran, Journal of Cases on Information Technology, 4(16), 38-57 (2018). https://doi.org/10.4018/jcit.2014100104

12. M. Krause, M. Mogalle, H. Pohl, and J.J. Williams, A playful game changer: Fostering student retention in online education with social gamification, in Proceedings of the Second ACM Conference on Learning@ Scale (L@S’ 15). Association for Computing Machinery, March 2015, Vancouver, BC, Canada, 95-102 (2015). https://doi.org/10.1145/2724660.2724665

13. J. Brand, Kahoot! Closes $\$ 10 \mathrm{~m}$ Financing Round To Help Improve Learning For All (2016). Accessed on: November 06, 2020. [Online]. Available:

https://medium.com/inside-kahoot/kahoot-closes-10m-financing-round-to-helpimprove-learning-for-all-9a6a8121309f 
14. I. Kurylev, LinguaLeo: uvlekayushchiye metody izucheniya angliyskogo yazyka [LinguaLeo: Fun English Learning Methods]. Gamification Now (n.d.). Accessed on: November 09, 2020. [Online]. Available: https://gamification-now.ru/cases/lingualeo

15. G.N. Ryazanova, E-management, 2, 40-54 (2020) 